Article

\title{
Do Religious Struggles Mediate the Association between Day-to-Day Discrimination and Depressive Symptoms?
}

\author{
Terrence D. Hill ${ }^{1, *}$, C. André Christie-Mizell ${ }^{2}$ (D), Preeti Vaghela ${ }^{3}$, Krysia N. Mossakowski ${ }^{4}$ \\ and Robert J. Johnson 5 (iD) \\ 1 School of Sociology, The University of Arizona, Social Sciences 400, P.O. Box 210027, Tucson, \\ AZ 85721-0027, USA \\ 2 Department of Sociology, Vanderbilt University, PMB 351811, Nashville, TN 37235-1811, USA; \\ andre.christie-mizell@vanderbilt.edu \\ 3 Department of Sociology, Florida State University, 600 W. College Avenue, Tallahassee, FL 32306, USA; \\ pmv11@my.fsu.edu \\ 4 Department of Sociology, University of Hawai'i at Mānoa, 2424 Mailem Way, Saunders 215, Honolulu, \\ HI 96822, USA; krysiam@hawaii.edu \\ 5 Department of Sociology, University of Miami, 5202 University Dr., Merrick Building, Rm 120, Coral Gables, \\ FL 33146, USA; rjohnson@miami.edu \\ * Correspondence: tdhil@email.arizona.edu; Tel.: +1-520-621-3804
}

Received: 7 June 2017; Accepted: 25 July 2017; Published: 27 July 2017

\begin{abstract}
Although numerous studies have shown that discrimination contributes to poorer mental health, the precise mechanisms underlying this association are not well understood. In this paper, we consider the possibility that the association between day-to-day discrimination (being disrespected, insulted, and harassed) and depressive symptoms is partially mediated by religious struggles (religious doubts and negative religious coping). To test our mediation model, we use data collected from the 2011 Miami-Dade Health Survey $(n=444)$ to estimate a series of multiple regression models assessing associations among day-to-day discrimination, religious struggles, and depressive symptoms. We find that day-to-day discrimination is positively associated with religious struggles and depressive symptoms, net of adjustments for general religious involvement, age, gender, race, ethnicity, immigrant status, interview language, education, employment, household income, financial strain, and marital status. We also observe that religious struggles are positively associated with depressive symptoms. Our mediation analyses confirm that day-to-day discrimination can contribute to depressive symptoms by stirring religious struggles. Our key finding is that religious struggles may serve as a maladaptive coping response to discrimination. Our analyses extend previous work by bridging research in the areas of discrimination, religious struggles, and mental health.
\end{abstract}

Keywords: discrimination; religious struggles; religious doubts; negative religious coping; depression

\section{Introduction}

For over two decades, numerous studies have shown that discrimination experiences-interpersonal abuse and injustice - can contribute to poorer mental health, including higher levels of anger, hostility, generalized anxiety, social anxiety, depression, paranoia, post-traumatic stress disorder, somatization, and non-specific psychological distress (Alvarez and Juang 2010; Borders and Liang 2011; Brown et al. 2000; Brown and Turner 2012; Feinstein et al. 2012; Fischer and Holz 2007; Gayman and Barragan 2013; Gee et al. 2006, 2007; Jackson et al. 1995; Keith et al. 2010; Kessler et al. 1999; Lee and Turney 2012; Miller et al. 2013; Moradi and Hasan 2004; Mossakowski 2003; Noh and Kaspar 2003; Paradies et al. 2015; Pascoe and Richman 2009; Schulz et al. 2006; Steffen and Bowden 2006; Taylor and Turner 2002; Vaghela and Sutin 2016; 
Versey and Curtin 2016; Williams et al. 2003; Yang and Park 2015). Although this body of work has made significant contributions to our understanding of the psychosocial costs associated with discrimination, the precise pathways to mental health have yet to be established. According to Williams and colleagues (Williams et al. 2003, p. 205), "one of the most critical needs is for more careful research attention to the specific mechanisms by which perceptions of discrimination might adversely affect health."

Over the years, researchers have speculated that discrimination might contribute to poorer mental health by exposing individuals to trauma, stress, structural strain, internalized oppression, feelings of ambiguity and loss, negative coping styles, substance use, sleep disturbance, and diminished psychosocial resources like meaning, self-esteem, and the sense of personal control (Brown et al. 2000; Clark et al. 1999; Gee et al. 2006; Paradies et al. 2015; Pascoe and Richman 2009; Williams et al. 2003). However, we could find only eleven direct empirical examinations of the mechanisms linking discrimination and mental health. Briefly, these studies indicate that the association between perceived discrimination and symptoms of psychological distress (anger, hostility, generalized anxiety, social anxiety, depression, and non-specific psychological distress) is at least partially mediated by self-esteem, the sense of personal control, sleep disturbance, structural strain (perceptions of structural and institutional barriers), rumination (brooding over problems), rejection sensitivity (expecting and overreacting to rejection), active coping (efforts to alleviate discrimination), support-seeking (pursuing support for discrimination), and avoidance coping (efforts to ignore discrimination) (Alvarez and Juang 2010; Borders and Liang 2011; Cassidy et al. 2004; Feinstein et al. 2012; Fischer and Holz 2007; Gayman and Barragan 2013; Keith et al. 2010; Moradi and Hasan 2004; Steffen and Bowden 2006; Versey and Curtin 2016; Yang and Park 2015).

In this paper, we extend previous research by proposing and testing a new potential mechanism. We consider the possibility that the association between day-to-day discrimination and depressive symptoms is mediated by religious struggles. Stauner and colleagues (Stauner et al. 2016, p. 1) define religious struggles as "tension and conflict about sacred matters within oneself, with others, and with the supernatural." There are three general dimensions of religious struggles: (1) Interpersonal; (2) Intrapersonal; and (3) Divine/Demonic (Exline et al. 2014). Interpersonal struggles refer to religious-based conflicts with family, friends, or less intimate relations within one's religious group or broader community. Intrapersonal struggles refer to intrapsychic battles with one's own religious beliefs and behavior, including struggles with internalized morality standards, religious doubts, and the search for meaning in life. While divine struggles refer to negative beliefs about or strained relationships with God or another higher power, demonic struggles refer to ominous beliefs about the devil or other evil spirits.

The idea that religious struggles could link discrimination experiences and mental health is a specific expression of a general conceptual model that has been developed in previous research (Ai et al. 2010; Ellison et al. 2010; Krause and Ellison 2009; Magyar-Russell and Pargament 2006; Park 2005; Wortmann et al. 2011). We call this general model the Strain-Struggles-Distress (S-S-D) model. The S-S-D model has two principle components. The first component (S-S) suggests that stressful experiences can lead to religious struggles. Magyar-Russell and Pargament (2006, p. 102) note that " ... negative life events, loss, and trauma often shatter previously held assumptions about the benevolence, fairness, and meaningfulness of the world. For many, this shattering of assumptions extends to the spiritual dimension of their lives." Indeed, several studies have traced the origins of religious struggles to a range of strains, including cancer, congestive heart failure, medical diagnoses, preoperative anxiety, disability, and other stressful or traumatic experiences (Ai et al. 2010; Ellison et al. 2010; Exline et al. 2011; Fitchett et al. 2004; Gall et al. 2009; Krause and Hayward 2012; Koenig et al. 1998; Wortmann et al. 2011). When experienced in the context of deeply held religious belief systems, it is often extremely difficult for people to find meaning in stressful events. In many ways, the events contradict the beliefs.

The second component (S-D) suggests that religious struggles can be psychologically distressing. Exline (2002, p. 182) explains that "religious belief and involvement can provide many benefits, 
including social support, a sense of meaning, purpose, and direction for one's life, an environment that fosters the development of virtue, and perhaps even a close, personal relationship with God. However, problems can arise in any of these areas, creating stumbling blocks that can create personal distress: ... interpersonal strains, negative attitudes toward God, inner struggles to believe, and problems associated with virtuous striving." While most studies of religion and mental health focus on the benefits, a growing body of research has begun to emphasize the so-called "dark side" of religion. In fact, several studies have linked religious struggles to a range of adverse mental health outcomes, including guilt, shame, anger, hostility, generalized anxiety, social anxiety, panic disorder, obsessive compulsive disorder, paranoia, depression, post-traumatic stress disorder, and non-specific psychological distress (Ai et al. 2010; Allen et al. 2008; Ano and Vasconcelles 2005; Ardelt and Koenig 2006; Bradshaw et al. 2008, 2010; Dillon and Wink 2007; Ellison 1991; Ellison et al. 2009, 2010, 2013, 2014; Ellison and Lee 2010; Exline et al. 1999, 2000, 2011, 2014, 2016; Exline and Martin 2005; Fenelon and Danielsen 2016; Fitchett et al. 2004; Galek et al. 2007; Gall et al. 2009; Hill and Cobb 2011; Hunsberger et al. 2002; Koenig et al. 1998; Krause et al. 1999; Krause and Wulff 2004; Krause and Ellison 2009; Krause 2006; Mannheimer and Hill 2015; McConnell et al. 2006; Nie and Olson 2016; Pargament et al. 2004; Smith et al. 2003; Stauner et al. 2016; Sternthal et al. 2010; Trenholm 1998; Uecker et al. 2016; Wilt et al. 2016a, 2016b, 2017; Wortmann et al. 2011). These general patterns are remarkably consistent and can be observed across indicators of religious struggle, including religious doubts, negative religious coping (e.g., feeling abandoned by God), anxious or distant attachments to the divine (e.g., God as unresponsive and cold), negative God images (e.g., God as vengeful and punitive), strained relationships within religious communities, ominous religious beliefs (e.g., believing that human nature is fundamentally perverse and corrupt), and religious cognitive dissonance (e.g., discrepancies between religious beliefs and behaviors).

The first component of our model (S-S) suggests that the intrapsychic challenges of discrimination are likely to trigger two specific forms of religious struggles: religious doubts and negative religious coping. Religious doubts are "feelings of uncertainty toward, or questioning of, religious teachings or beliefs" (Hunsberger et al. 1993, p. 28). Negative religious coping refers to precarious adaptations to stressful events, including "a tenuous relationship with God, spiritual struggle, and a threatening view of the world" (Pargament et al. 1998, p. 720). Suffering challenges religious beliefs systems and sows the seeds of doubt (Exline and Rose 2005). Suffering leads people to question their gods (Pargament et al. 2005). Eventually suffering leads people to search for meaning in their lives by asking fundamental questions (Exline et al. 2011; Grubbs and Exline 2014; Pargament et al. 2004, 2005; Park 2005). How can this happen to me when I am a person of faith? If God truly loves me, why do I suffer? Has God abandoned me? Is God punishing me? Systematic and repeated experiences with discrimination-interpersonal abuse and injustice-are inherently stressful and potentially traumatic (Clark et al. 1999; Gee et al. 2006; Kessler et al. 1999; Williams et al. 2003). Our central argument is that the suffering associated with discrimination can lead to religious doubts and negative religious coping by shattering important beliefs about the benevolence of God, fairness in the world that is bestowed on the faithful, and the sense of meaning that should accompany religious dedication.

The second component of our model (S-D) suggests that religious doubts and negative religious coping are emotionally distressing. Religious doubts and negative religious coping are destabilizing because they indicate that established religious belief systems are no longer adequate to explain personal experiences with suffering and injustice (Exline et al. 2016; Grubbs and Exline 2014; Magyar-Russell and Pargament 2006; Pargament et al. 2005; Park 2005; Wilt et al. 2016a). Religious doubts and negative religious coping are stressful and distressing because they contribute to religious cognitive dissonance, negative constituent emotions (e.g., guilt, shame, fear, and anger), interpersonal strains, a sense of powerlessness, and low self-esteem (Ellison 1991; Ellison and Lee 2010; Ellison et al. 2010; Exline 2002; Exline and Rose 2013; Galek et al. 2007; Hill and Cobb 2011; Hunsberger et al. 2002; Krause et al. 1999; Krause and Wulff 2004; Krause 2006; 
Krause and Ellison 2009; Magyar-Russell and Pargament 2006; Pargament et al. 2004, 2005; Park 2005; Uecker et al. 2016; Wortmann et al. 2011).

Based on the general Strain-Struggles-Distress (S-S-D) model and previous empirical research, we hypothesize that the association between day-to-day discrimination and depressive symptoms will be partially mediated or explained by religious struggles (see Figure 1). In other words, we expect that day-to-day discrimination will contribute to symptoms of depression by stirring religious struggles-religious doubts and bouts of negative religious coping.

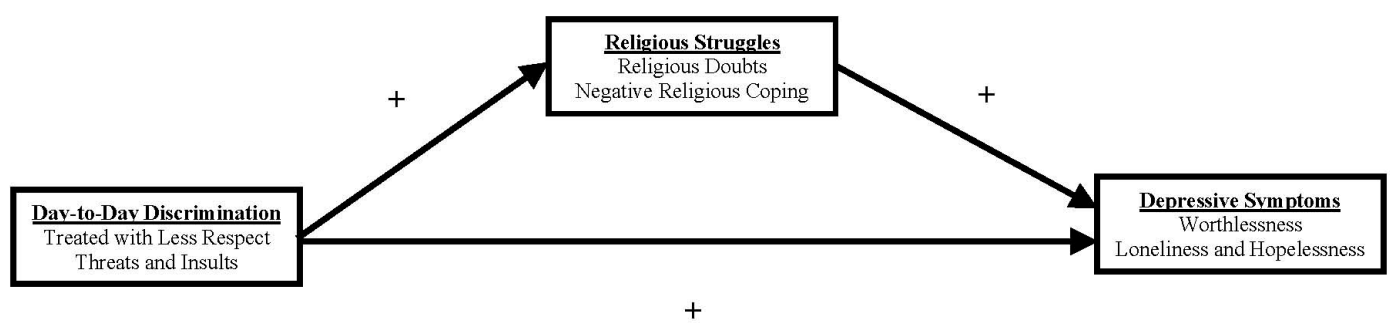

Figure 1. Conceptual Model Linking Day-to-Day Discrimination and Depressive Symptoms with Religious Struggles.

\section{Materials and Methods}

\subsection{Data}

The data for this study come from the 2011 Miami-Dade Health Survey (MDHS). The MDHS is based on a county-wide probability sample of 444 community-dwelling adults aged 18 and over residing in Miami-Dade County. Survey Sampling, Inc. generated the sample using a random-digit dialing design. The Office of Survey Research at the University of Texas at Austin executed the data collection process, which yielded a response rate of $60 \%$. The average computer-assisted telephone interview lasted approximately $45 \mathrm{~min}$. The survey instrument was translated into Spanish using a back-translation procedure that included an English to Spanish translation by one translator, a Spanish to English translation by a second translator, and a comparison and reconciliation of translation discrepancies by a third translator. Surveys were administered by Spanish-speaking interviewers for respondents who were more comfortable answering in that language. The primary purpose of the MDHS is to examine the social life, health, and well-being of a unique and understudied population of adults living in Miami-Dade County. The data include detailed information concerning (1) the neighborhood environment; (2) psychosocial characteristics; (3) religious involvement; (4) immigration and acculturation; (5) race/ethnic identity and discrimination; (6) health behaviors; (7) physical health; (8) mental health; and (9) general sociodemographic characteristics.

\subsection{Measures}

Depressive Symptoms are measured as the mean response to five items from the Brief Symptom Inventory (BSI-18) (Derogatis 2000). Respondents were asked to indicate how much in the past seven days they were distressed or bothered by (a) feeling blue; (b) feelings of worthlessness; (c) feeling no interest in things; (d) feeling lonely; and (e) feeling hopeless about the future $(\alpha=0.80)$. Response categories for each item range from 0 (not at all) to 4 (extremely). Table 1 presents survey items and component loadings for depressive symptoms. All loadings were estimated using principal components analysis, specifying a minimum eigenvalue of 1.00 , with varimax rotation. We observe only one component, and all component loadings exceed 0.60 . Because the original depression index was positively skewed, subsequent multivariate analyses employ a square root transformation. After the transformation, skewness and kurtosis estimates were reduced from 2.35 and 6.32 to 0.87 and 0.16 , respectively. During pre-testing, one of the original BSI-18 depression items (thoughts of ending your life) was eliminated due to unusually high non-response rates. 
Day-to-Day Discrimination is measured as the mean response to seven items $(\alpha=0.79)$ developed in previous research (Williams et al. 1997). Respondents were asked to indicate how often (in their day-to-day lives) they experienced (a) being called names or being insulted; (b) people acting as if they think you were not smart; (c) being treated with less respect than other people; (d) people acting as if they are better than you; (e) being threatened or harassed; (f) people acting as if they think you are dishonest; and (g) people acting as if they are afraid of you. Response categories for each item range from 0 (never) to 4 (very often). Table 1 also presents survey items and component loadings for day-to-day discrimination. We observe only one component, and all component loadings exceed 0.50 . Two items (being treated with less courtesy than other people and receiving poorer service than other people at restaurants or stores) were excluded from our index due to low component loadings.

Table 1. Items and Component Loadings for Focal Measures $(n=444)$.

\begin{tabular}{|c|c|c|c|}
\hline & $\begin{array}{l}\text { Depressive } \\
\text { Symptoms }\end{array}$ & $\begin{array}{c}\text { Day-to-Day } \\
\text { Discrimination }\end{array}$ & $\begin{array}{l}\text { Religious } \\
\text { Struggles }\end{array}$ \\
\hline 1. Distressed or bothered by feeling blue & 0.84 & & \\
\hline 2. Distressed or bothered by feelings of worthlessness & 0.77 & & \\
\hline 3. Distressed or bothered by feeling no interest in things & 0.76 & & \\
\hline 4. Distressed or bothered by feeling lonely & 0.72 & & \\
\hline 5. Distressed or bothered by feeling hopeless about future & 0.67 & & \\
\hline 6. You are called names or insulted & & 0.76 & \\
\hline 7. People act as if they think you are not smart & & 0.71 & \\
\hline 8. You are treated with less respect than other people & & 0.69 & \\
\hline 9. People act as if they're better than you are & & 0.69 & \\
\hline 10. You are threatened or harassed & & 0.68 & \\
\hline 11. People act as if they think you are dishonest & & 0.64 & \\
\hline 12. People act as if they are afraid of you & & 0.53 & \\
\hline 13. You feel that God is punishing you for your sins & & & 0.79 \\
\hline 14. You wonder whether God has abandoned you & & & 0.75 \\
\hline 15. You have doubts about your religious or spiritual beliefs & & & 0.60 \\
\hline Eigenvalues & 2.86 & 3.18 & 1.55 \\
\hline
\end{tabular}

Source: Miami-Dade Health Survey (2011).

Religious struggles are measured as the mean response to three items $(\alpha=0.54)$ drawn from previous research (Idler et al. 2003; Krause 2006; Pargament et al. 2005). Two items indicate negative religious coping. Respondents were asked the following questions: When bad things happen in your life, how often do you feel that God is punishing you for your sins? When bad things happen in your life, how often do you wonder whether God has abandoned you? The third item indicates religious doubts. Respondents were asked the following questions: How often do you have doubts about your religious or spiritual beliefs? Responses for all three items range from 0 (never) to 4 (very often). Table 1 presents survey items and component loadings for religious struggles. Although religious doubts and religious coping are often treated as separate constructs in previous research, we observe only one component. This suggests that a single underlying concept (religious struggles) is driving responses to all three items. All component loadings exceed 0.60 .

Following previous research (Brown et al. 2000; Ellison et al. 2009; Gee et al. 2006; Krause and Wulff 2004; Ida and Christie-Mizell 2012; Pargament et al. 2004), subsequent regression analyses adjust for known correlates of discrimination experiences, religious struggles, and mental health. These background variables include age (in years), gender ( $1=$ female, $0=$ male), race (dummy variables for Non-Hispanic White, Non-Hispanic Black, Hispanic, and Other Race/Ethnicity, with Non-Hispanic White serving as the reference category), immigrant status ( $1=$ US-born, $0=$ immigrant), language of interview ( $1=$ Spanish, $0=$ English), education (ordinal variable ranging from $0=$ less than high school education to 3 = graduate level education), employment status $(1=$ employed, $0=$ otherwise), household income (ordinal variable ranging from $0=\$ 5000-\$ 10,000$ to $9=$ more than $\$ 125,000)$, and marital status ( $1=$ married, $0=$ otherwise). We measure financial strain as the 
mean response to three items $(\alpha=0.61)$. Respondents were asked to indicate the extent to which they had (a) limited financial resources; (b) difficulty paying bills; and (c) enough money to afford housing, food, and clothing. We measure religious involvement as the mean response to six items $(\alpha=0.85)$. Respondents were asked to indicate how often they (a) spend time in private religious activities, such as prayer, meditation or Bible study; (b) attend church, synagogue, or other religious meetings; (c) look to God for strength, support, and guidance; (d) find a lesson from God when bad things happen and the degree to which they (e) experience the presence of God in daily life; and (f) try hard to carry religion over into all areas of life. To account for mixed question formats and response categories, each religious involvement item was standardized before indexing. Pascoe and colleagues (Pascoe et al. 2016) have described the the psychometric properties of these items.

\subsection{Statistical Procedures}

Table 2 provides descriptive statistics for all study variables, including variable ranges, sample means, standard deviations, and alpha reliability estimates. In multivariate analyses, we employ ordinary least squares (OLS) regression to model our two continuous outcomes (religious struggles and depressive symptoms). Table 3 provides unstandardized OLS regression coefficients for all independent variables. Unstandardized OLS coefficients represent the estimated difference in the mean of $Y$ for those who are one unit apart on $X$, controlling for all other predictors in the model. We use conditional process analysis to formally assess our mediation model (Hayes 2013). Figure 2 provides unstandardized indirect effects and $95 \%$ bias corrected bootstrap confidence intervals. Bootstrap confidence intervals are preferable to normal theory based Sobel tests because indirect effects (products of component paths) are not normally distributed (Hayes 2013). We used multiple imputation by chained equations to replace missing values on all independent and dependent variables (White et al. 2011).

\section{Results}

\subsection{Descriptive Analyses}

As shown in Table 2, respondents tend to exhibit low levels of day-to-day discrimination, religious struggles, and depression. The average age of the sample is 57 years. The clear majority $(70 \%)$ of respondents are women. In terms of race and ethnicity, the sample consists of Non-Hispanic whites $(31 \%)$, Hispanic Americans (41\%), Non-Hispanic blacks (14\%), and those of other races and ethnicities $(14 \%)$. Approximately half of the respondents are US-born, and nearly one third completed the interview in Spanish. The average respondent had at least some college experience, and almost half of the sample was employed. The average respondent reported household income in the range of $\$ 35,000$ and $\$ 50,000$ and low levels of financial strain. The majority (59\%) of respondents were married. Overall, the sample exhibited moderate levels of general religious involvement. 
Table 2. Descriptive Statistics $(n=444)$.

\begin{tabular}{lcccc}
\hline & Range & Mean & Standard Dev. & Alpha Reliability \\
\hline Day-to-Day Discrimination & $0-4$ & 0.52 & 0.56 & 0.79 \\
Depressive Symptoms & $0-4$ & 0.42 & 0.68 & 0.80 \\
Religious Struggles & $0-4$ & 0.54 & 0.69 & 0.54 \\
Age & $18-95$ & 56.65 & 16.65 & \\
Female & $0-1$ & 0.70 & & \\
Non-Hispanic White & $0-1$ & 0.31 & & \\
Non-Hispanic Black & $0-1$ & 0.14 & & \\
Hispanic & $0-1$ & 0.41 & & \\
Other Race/Ethnicity & $0-1$ & 0.14 & & \\
US-Born & $0-1$ & 0.47 & & \\
Spanish Interview & $0-1$ & 0.31 & & \\
Education & $0-3$ & 1.27 & 1.14 & \\
Employed & $0-1$ & 0.45 & & \\
Household Income & $0-9$ & 4.83 & 2.69 & \\
Financial Strain & $0-4$ & 1.28 & 1.01 & \\
Married & $0-1$ & 0.62 & & \\
Religious Involvement & $-2.04-1.24$ & -0.01 & 0.77 & \\
\hline
\end{tabular}

Source: Miami-Dade Health Survey (2011).

Table 3. OLS Regression of Religious Struggles and Depressive Symptoms $(n=444)$.

\begin{tabular}{|c|c|c|c|c|c|c|}
\hline \multirow[b]{2}{*}{ Day-to-Day Discrimination } & \multicolumn{2}{|c|}{ Religious Struggles } & \multicolumn{4}{|c|}{ Depressive Symptoms } \\
\hline & 0.299 & $* * *$ & 0.194 & $* * *$ & 0.167 & $* * *$ \\
\hline Religious Struggles & & & & & 0.092 & $* *$ \\
\hline Age & -0.004 & & -0.001 & & -0.000 & \\
\hline Female & 0.083 & & 0.071 & & 0.064 & \\
\hline Hispanic & 0.025 & & -0.021 & & -0.024 & \\
\hline Non-Hispanic Black & -0.065 & & -0.098 & & -0.092 & \\
\hline Other Race/Ethnicity & 0.118 & & -0.002 & & -0.013 & \\
\hline US-Born & -0.225 & * & 0.012 & & 0.033 & \\
\hline Spanish Interview & -0.216 & & 0.156 & * & 0.176 & ** \\
\hline Education & -0.020 & & 0.002 & & 0.004 & \\
\hline Employed & -0.080 & & -0.132 & * & -0.124 & * \\
\hline Household Income & 0.003 & & -0.003 & & -0.003 & \\
\hline Financial Strain & 0.035 & & 0.103 & $* * *$ & 0.099 & $* * *$ \\
\hline Married & 0.184 & $* *$ & -0.117 & $*$ & -0.134 & $* *$ \\
\hline Religious Involvement & -0.061 & & -0.048 & & -0.043 & \\
\hline $\mathrm{R}$-squared & 0.133 & & 0.171 & & 0.187 & \\
\hline
\end{tabular}

\subsection{Multivariate Analyses}

According to the first column of Table 3, day-to-day discrimination is positively associated with religious struggles, net of controls for age, gender, race, ethnicity, immigrant status, interview language, education, employment status, household income, financial strain, marital status, and general religious involvement. In other words, respondents who report more experiences with being disrespected, insulted, and harassed also tend to report more religious doubts and more bouts of negative religious coping.

In the second column of Table 3, we find that day-to-day discrimination is positively associated with depressive symptoms. When religious struggles are controlled, the association between day-to-day discrimination and depression is reduced by approximately $14 \%$, but remains statistically significant. This pattern suggests that respondents who report more experiences with insults, threats, and injustice also tend to report more symptoms of depression like feeling worthless, lonely, and hopeless about the 
future. In our fully adjusted model (the third column of Table 3), we observe that religious struggles are also positively associated with depressive symptoms. These results suggest that respondents who report more religious doubts and more frequent use of negative religious coping also tend to report more symptoms of depression.

Figure 2 presents our formal mediation analyses, including the indirect effect, 95\% bias corrected bootstrap confidence interval, and the conservative Sobel test. The indirect effect of day-to-day discrimination on depression through religious struggles is different from zero. This is indicated by the confidence interval that does not contain zero and the statistically significant Sobel test $(z=2.44$, $p<0.05)$. Taken together, these results indicate that religious struggles partially mediate the association between day-to-day discrimination and depression.

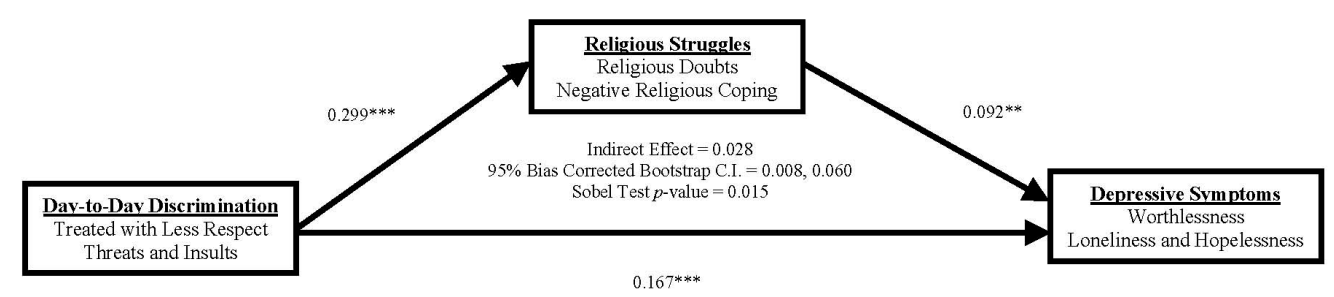

Figure 2. Empirical Model Linking Day-to-Day Discrimination and Depressive Symptoms with Religious Struggles.

\section{Discussion}

Although the association between discrimination experiences and mental health is well established, the precise mechanisms are not. To extend previous research, we considered the possibility that the association between day-to-day discrimination and depressive symptoms is at least partially mediated by religious struggles. We found that discrimination experiences were positively associated with religious struggles and depressive symptoms. We also observed that the positive association between discrimination and depression was partially mediated by religious struggles. In the end, our model suggested that religious struggles could serve as a maladaptive coping response to socially patterned experiences with discrimination.

Our results are consistent with previous studies of discrimination and depression (Brown et al. 2000; Gayman and Barragan 2013; Gee et al. 2006, 2007; Keith et al. 2010; Kessler et al. 1999; Lee and Turney 2012; Miller et al. 2013; Mossakowski 2003; Noh and Kaspar 2003; Paradies et al. 2015; Pascoe and Richman 2009; Schulz et al. 2006; Steffen and Bowden 2006; Taylor and Turner 2002; Vaghela and Sutin 2016; Versey and Curtin 2016; Williams et al. 2003). Our findings also confirm previous examinations of religious struggles and depression (Ano and Vasconcelles 2005; Exline et al. 1999, 2000, 2014, 2016; Fitchett et al. 2004; Galek et al. 2007; Koenig et al. 1998; Krause et al. 1999; Krause and Wulff 2004; McConnell et al. 2006; Pargament et al. 2004; Stauner et al. 2016; Uecker et al. 2016; Wilt et al. 2016b). Previous studies have linked various stressors (mostly health problems) with religious struggles (Ai et al. 2010; Ellison et al. 2010; Exline et al. 2011; Fitchett et al. 2004; Gall et al. 2009; Krause and Hayward 2012; Koenig et al. 1998; Wortmann et al. 2011). To our knowledge, we are the first study to connect discrimination experiences with religious struggles. Prior work indicates that the association between discrimination and mental health is as least partially mediated by self-esteem, sleep disturbance, the sense of personal control, structural strain, and a range of adverse coping strategies (Alvarez and Juang 2010; Borders and Liang 2011; Cassidy et al. 2004; Feinstein et al. 2012; Fischer and Holz 2007; Moradi and Hasan 2004; Steffen and Bowden 2006; Versey and Curtin 2016; Yang and Park 2015). We introduce religious struggles as yet another mechanism linking discrimination and depression and provide additional support for the general Strain-Struggles-Distress model.

We acknowledge that our work should be considered in the context of several limitations. First and foremost, all analyses are based on cross-sectional data. As a result, it is difficult to determine the direction of the relationships among discrimination experiences, religious struggles, and depressive 
symptoms. Although previous theory suggests that discrimination and religious struggles can contribute to depression, preexisting symptoms of depression might also contribute to perceptions of discrimination, religious doubts, and negative religious coping. Depression is often characterized by a negative cognitive bias, which can shape the way individuals experience their environments and interpret the world around them. By driving a generally pessimistic orientation toward life, depression could, for example, increase perceptions that one is being discriminated against or beliefs about punishing gods. Although previous longitudinal studies tend to support our proposed conceptual model (e.g., Krause 2006; Nie and Olson 2016; Pargament et al. 2004; Schulz et al. 2006), prospective data are needed for verification over time. Although our proposed model is theoretically viable, we cannot exclude the possibility of alternative conceptual models. For example, religious doubts could contribute to symptoms of depression by provoking social sanctions or social conflicts within religious communities (i.e., Struggles-Strain-Distress).

The current study is also limited by our three-item measurement of religious struggles. Although results obtained from an exploratory principal components analysis confirm that these items are sound indicators, reliability is rather low due to the small number of items. Such low reliability suggests that any observed associations are likely to be conservative. This could help to explain why the standardized coefficient for religious struggles (not shown) is smaller in magnitude than the coefficients for our other statistically significant predictors of depressive symptoms. In future research, our analyses should be replicated using more complex and sophisticated measurements of religious struggles (see Exline et al. 2014; Pargament et al. 2004; Stauner et al. 2016). It is also important to examine specific elements of religious struggles (e.g., religious doubts) as potential mechanisms of strain. Research along these lines could provide a more theoretically nuanced understanding of the processes linking strain and distress.

Generalizability is another issue. Most studies of religious struggles are limited to data collected from non-probability samples because large epidemiological surveys rarely include these types of measurements. The use of data collected from a probability sample of Miami-Dade adults clearly advances this body of work, but we cannot overstate the external validity of our conceptual model. Additional research with data collected from national probability samples or other regional probability samples is needed to confirm our results.

Our final limitation is sample size. Because our sample is so small, we were unable to seriously consider any potential subgroup variations in our proposed model. In exploratory analyses (not shown), we estimated a moderated mediation model (Hayes 2013) to assess whether the indirect effect of discrimination on depression through religious struggles varied according to race and ethnicity. We found that the indirect effect of present in non-Hispanic whites $(95 \%$ C.I. $=0.028,0.184)$, but not non-whites $(95 \%$ C.I. $=-0.006,0.042)$. The index of moderated mediation confirmed that the difference in the indirect effects was statistically significant $(95 \%$ C.I. $=0.013,0.170)$. These results suggest that the indirect effect of discrimination on depression through religious struggles was more pronounced for non-Hispanic whites. This pattern was apparently driven by race/ethnic variations in the association between religious struggles and depression, not the association between discrimination and religious struggles. If these patterns can be trusted (given the limitations of our sample), they could be explained by race differences in divine attachments and God images (Froese and Bader 2010; Kirkpatrick 1992). If non-Hispanic whites are more likely to have anxious or distant or insecure attachments to the divine and tend to hold more negative or punitive images of God, it is reasonable to expect that religious struggles would be especially distressing for whites. Of course the veracity of these patterns and theories are contingent upon replication and further testing with larger samples.

\section{Conclusions}

Our key finding is that the established association between discrimination and depressive symptoms is partially mediated by religious struggles. Although our analyses extend previous work by bridging research in the areas of discrimination and religious struggles, much remains to be 
done. As we move forward, we should consider several important questions: How do discrimination experiences lead to religious struggles? Why are religious struggles depressing? Does the indirect effect of discrimination on depression through religious struggles vary according to theoretically relevant subgroups (e.g., race and gender)? Does the indirect effect of discrimination through religious struggles extend to other indicators of mental health (e.g., anxiety or chemical dependency)? Answers to these questions would make significant contributions to multiple literatures and help to further develop the general Strain-Struggles-Distress model.

Author Contributions: Terrence Hill and André Christie-Mizell conceived of and designed the study. Terrence Hill analyzed the data. All authors made significant contributions to background research, writing, and the interpretation of our empirical analyses. Terrence Hill, Krysia Mossakowski, and Robert Johnson served as the Principal Investigators of the Miami-Dade Health Survey.

Conflicts of Interest: The authors declare no conflict of interest.

\section{References}

Ai, Amy Lee, Kenneth Pargament, Ziad Kronfol, Terrence N. Tice, and Hoa Appel. 2010. Pathways to Postoperative Hostility in Cardiac Patients Mediation of Coping, Spiritual Struggle and Interleukin-6. Journal of Health Psychology 15: 186-95. [CrossRef] [PubMed]

Allen, Rebecca S., Laura Lee Phillips, Lucinda Lee Roff, Ronald Cavanaugh, and Laura Day. 2008. Religiousness/spirituality and mental health among older male inmates. The Gerontologist 48: 692-97. [CrossRef] [PubMed]

Alvarez, Alvin N., and Linda P. Juang. 2010. Filipino Americans and racism: A multiple mediation model of coping. Journal of Counseling Psychology 57: 167-78. [CrossRef] [PubMed]

Ano, Gene G., and Erin B. Vasconcelles. 2005. Religious coping and psychological adjustment to stress: A meta-analysis. Journal of Clinical Psychology 61: 461-80. [CrossRef] [PubMed]

Ardelt, Monika, and Cynthia S. Koenig. 2006. The role of religion for hospice patients and relatively healthy older adults. Research on Aging 28: 184-215. [CrossRef]

Borders, Ashley, and Christopher T. H. Liang. 2011. Rumination partially mediates the associations between perceived ethnic discrimination, emotional distress, and aggression. Cultural Diversity and Ethnic Minority Psychology 17: 125-33. [CrossRef] [PubMed]

Bradshaw, Matt, Christopher G. Ellison, and Kevin J. Flannelly. 2008. Prayer, God imagery, and symptoms of psychopathology. Journal for the Scientific Study of Religion 47: 644-59. [CrossRef]

Bradshaw, Matt, Christopher G. Ellison, and Jack P. Marcum. 2010. Attachment to God, images of God, and psychological distress in a nationwide sample of Presbyterians. The International Journal for the Psychology of Religion 20: 130-47. [CrossRef] [PubMed]

Brown, Tony N., David R. Williams, James S. Jackson, Harold W. Neighbors, Myriam Torres, Sherrill L. Sellers, and Kendrick T. Brown. 2000. "Being black and feeling blue": The mental health consequences of racial discrimination. Race and Society 2: 117-31. [CrossRef]

Brown, Robyn Lewis, and R. Jay Turner. 2012. Physical limitation and anger: Stress exposure and assessing the role of psychosocial resources. Society and Mental Health 2: 69-84. [CrossRef]

Cassidy, Clare, Rory C. O'connor, Christine Howe, and David Warden. 2004. Perceived discrimination and psychological distress: The role of personal and ethnic self-esteem. Journal of Counseling Psychology 51: 329-39. [CrossRef]

Clark, Rodney, Norman B. Anderson, Vernessa R. Clark, and David R. Williams. 1999. Racism as a stressor for African Americans: A biopsychosocial model. American Psychologist 54: 805-16. [CrossRef] [PubMed]

Derogatis, Leonard. 2000. Brief Symptom Inventory 18, Administration, Scoring, and Procedures Manual. Minneapolis: National Computer System.

Dillon, Michele, and Paul Wink. 2007. In the Course of a Lifetime: Tracing Religious Belief, Practice and Change. Berkeley: University of California Press.

Ellison, Christopher G. 1991. Religious involvement and subjective well-being. Journal of Health and Social Behavior 32: 80-99. [CrossRef] [PubMed] 
Ellison, Christopher G., Amy M. Burdette, and Terrence D. Hill. 2009. Blessed assurance: Religion, anxiety, and tranquility among US adults. Social Science Research 38: 656-67. [CrossRef] [PubMed]

Ellison, Christopher G., and Jinwoo Lee. 2010. Spiritual struggles and psychological distress: Is there a dark side of religion? Social Indicators Research 98: 501-17. [CrossRef]

Ellison, Christopher G., Lori A. Roalson, Janelle M. Guillory, Kevin J. Flannelly, and John P. Marcum. 2010. Religious resources, spiritual struggles, and mental health in a nationwide sample of PCUSA clergy. Pastoral Psychology 59: 287-304. [CrossRef]

Ellison, Christopher G., Qijuan Fang, Kevin J. Flannelly, and Rebecca A. Steckler. 2013. Spiritual struggles and mental health: Exploring the moderating effects of religious identity. International Journal for the Psychology of Religion 23: 214-29. [CrossRef]

Ellison, Christopher G., Matt Bradshaw, Kevin J. Flannelly, and Kathleen C. Galek. 2014. Prayer, attachment to God, and symptoms of anxiety-related disorders among US adults. Sociology of Religion 75: 208-33. [CrossRef]

Exline, Julie Juola, Ann Marie Yali, and Marci Lobel. 1999. When God disappoints: Difficulty forgiving God and its role in negative emotion. Journal of Health Psychology 4: 365-79. [CrossRef] [PubMed]

Exline, Julie Juola, Ann Marie Yali, and William C. Sanderson. 2000. Guilt, discord, and alienation: The role of religious strain in depression and suicidality. Journal of Clinical Psychology 56: 1481-96. [CrossRef]

Exline, Julie Juola. 2002. Stumbling blocks on the religious road: Fractured relationships, nagging vices, and the inner struggle to believe. Psychological Inquiry 13: 182-89. [CrossRef]

Exline, Julie Juola, and Alyce Martin. 2005. Anger toward God: A new frontier in forgiveness research. In Handbook of Forgiveness Research. Edited by Everett L. Worthington Jr. New York: Guilford Press, pp. 73-88.

Exline, Julie Juola, and Eric Rose. 2005. Religious and spiritual struggles. In Handbook of the Psychology of Religion and Spirituality. Edited by Raymond F. Paloutzian and Crystal L. Park. New York: Guilford Press, pp. 315-30.

Exline, Julie J., Crystal L. Park, Joshua M. Smyth, and Michael P. Carey. 2011. Anger toward God: Social-cognitive predictors, prevalence, and links with adjustment to bereavement and cancer. Journal of Personality and Social Psychology 100: 129-48. [CrossRef] [PubMed]

Exline, Julie Juola, and Eric Rose. 2013. Religious and spiritual struggles. In Handbook of the Psychology of Religion and Spirituality. Edited by Raymond F. Paloutzian and Crystal L. Park. New York: Guilford Press, pp. 380-98.

Exline, Julie J., Kenneth I. Pargament, Joshua B. Grubbs, and Ann Marie Yali. 2014. The Religious and Spiritual Struggles Scale: Development and initial validation. Psychology of Religion and Spirituality 6: $208-22$. [CrossRef]

Exline, Julie J., Steven J. Krause, and Karen A. Broer. 2016. Spiritual Struggle among Patients Seeking Treatment for Chronic Headaches: Anger and Protest Behaviors toward God. Journal of Religion and Health 55: $1729-47$. [CrossRef] [PubMed]

Feinstein, Brian A., Marvin R. Goldfried, and Joanne Davila. 2012. The relationship between experiences of discrimination and mental health among lesbians and gay men: An examination of internalized homonegativity and rejection sensitivity as potential mechanisms. Journal of Consulting and Clinical Psychology 80: 917-27. [CrossRef] [PubMed]

Fenelon, Andrew, and Sabrina Danielsen. 2016. Leaving my religion: Understanding the relationship between religious disaffiliation, health, and well-being. Social Science Research 57: 49-62. [CrossRef] [PubMed]

Fischer, Ann R., and Kenna Bolton Holz. 2007. Perceived discrimination and women's psychological distress: The roles of collective and personal self-esteem. Journal of Counseling Psychology 54: 154-64. [CrossRef]

Fitchett, George, Patricia E. Murphy, Jo Kim, James L. Gibbons, Jacqueline R. Cameron, and Judy A. Davis. 2004. Religious struggle: Prevalence, correlates and mental health risks in diabetic, congestive heart failure, and oncology patients. The International Journal of Psychiatry in Medicine 34: 179-96. [CrossRef] [PubMed]

Froese, Paul, and Christopher Bader. 2010. America's Four Gods: What We Say about God and What that Says about Us. Oxford: Oxford University Press.

Galek, Kathleen, Neal Krause, Christopher G. Ellison, Taryn Kudler, and Kevin J. Flannelly. 2007. Religious doubt and mental health across the lifespan. Journal of Adult Development 14: 16-25. [CrossRef]

Gall, Terry Lynn, Elizabeth Kristjansson, Claire Charbonneau, and Peggy Florack. 2009. A longitudinal study on the role of spirituality in response to the diagnosis and treatment of breast cancer. Journal of Behavioral Medicine 32: 174-86. [CrossRef] [PubMed] 
Gayman, Mathew D., and Juan Barragan. 2013. Multiple perceived reasons for major discrimination and depression. Society and Mental Health 3: 203-20. [CrossRef]

Gee, Gilbert C., Andrew Ryan, David J. Laflamme, and Jeanie Holt. 2006. Self-reported discrimination and mental health status among African descendants, Mexican Americans, and other Latinos in the New Hampshire REACH 2010 Initiative: The added dimension of immigration. American Journal of Public Health 96: 1821-28. [CrossRef] [PubMed]

Gee, Gilbert C., Michael Spencer, Juan Chen, Tiffany Yip, and David T. Takeuchi. 2007. The association between self-reported racial discrimination and 12-month DSM-IV mental disorders among Asian Americans nationwide. Social Science E Medicine 64: 1984-96.

Grubbs, Joshua B., and Julie J. Exline. 2014. Why Did God Make Me This Way? Anger at God in the Context of Personal Transgressions. Journal of Psychology \& Theology 42: 315-25.

Hayes, Andrew. 2013. Introduction to Mediation, Moderation, and Conditional Processes Analysis: A Regression-Based Approach. New York: The Guilford Press.

Hill, Terrence D., and Ryon Cobb. 2011. Religious involvement and religious struggles. In Toward a Sociological Theory of Religion and Health. Edited by Anthony J. Blasi. Leiden: Brill, pp. 239-60.

Hunsberger, Bruce, Barbara McKenzie, Michael Pratt, and S. Mark Pancer. 1993. Religious doubt: A social psychological analysis. Research in the Social Scientific Study of Religion 5: 27-51.

Hunsberger, Bruce, Michael Pratt, and S. Mark Pancer. 2002. A longitudinal study of religious doubts in high school and beyond: Relationships, stability, and searching for answers. Journal for the Scientific Study of Religion 41: 255-66. [CrossRef]

Ida, Aya Kimura, and C. André Christie-Mizell. 2012. Racial group identity, psychosocial resources, and depressive symptoms: Exploring ethnic heterogeneity among black Americans. Sociological Focus 45: 41-62. [CrossRef]

Idler, Ellen L., Marc A. Musick, Christopher G. Ellison, Linda K. George, Neal Krause, Marcia G. Ory, Kenneth I. Pargament, Lynda H. Powell, Lynn G. Underwood, and David R. Williams. 2003. Measuring multiple dimensions of religion and spirituality for health research: Conceptual background and findings from the 1998 General Social Survey. Research on Aging 25: 327-65. [CrossRef]

Jackson, James S., Tony N. Brown, David R. Williams, Myriam Torres, Sherrill L. Sellers, and Kendrick Brown. 1995. Racism and the physical and mental health status of African Americans: A thirteen year national panel study. Ethnicity \& Disease 6: 132-47.

Keith, Verna M., Karen D. Lincoln, Robert Joseph Taylor, and James S. Jackson. 2010. Discriminatory experiences and depressive symptoms among African American women: Do skin tone and mastery matter? Sex Roles 62: 48-59. [CrossRef] [PubMed]

Kessler, Ronald C., Kristin D. Mickelson, and David R. Williams. 1999. The prevalence, distribution, and mental health correlates of perceived discrimination in the United States. Journal of Health and Social Behavior 40: 208-30. [CrossRef] [PubMed]

Kirkpatrick, Lee A. 1992. An attachment-theory approach psychology of religion. The International Journal for the Psychology of Religion 2: 3-28. [CrossRef]

Krause, Neal, Berit Ingersoll-Dayton, Christopher G. Ellison, and Keith M. Wulff. 1999. Aging, religious doubt, and psychological well-being. The Gerontologist 39: 525-33. [CrossRef] [PubMed]

Krause, Neal, and Keith M. Wulff. 2004. Religious doubt and health: Exploring the potential dark side of religion. Sociology of Religion 65: 35-56. [CrossRef]

Krause, Neal. 2006. Religious doubt and psychological well-being: A longitudinal investigation. Review of Religious Research 47: 287-302.

Krause, Neal, and Christopher G. Ellison. 2009. The doubting process: A longitudinal study of the precipitants and consequences of religious doubt in older adults. Journal for the Scientific Study of Religion 48: 293-312. [CrossRef] [PubMed]

Krause, Neal, and R. David Hayward. 2012. Humility, lifetime trauma, and change in religious doubt among older adults. Journal of Religion and Health 51: 1002-16. [CrossRef] [PubMed]

Koenig, Harold G., Kenneth I. Pargament, and Julie Nielsen. 1998. Religious coping and health status in medically ill hospitalized older adults. The Journal of Nervous and Mental Disease 186: 513-21. [CrossRef] [PubMed]

Lee, Hedwig, and Kristin Turney. 2012. Investigating the relationship between perceived discrimination, social status, and mental health. Society and Mental Health 2: 1-20. [CrossRef] [PubMed] 
Magyar-Russell, Gina, and Kenneth Pargament. 2006. The darker side of religion: Risk factors for poorer health and well-being. In Where God and Man Meet: How the Brain and Evolutionary Studies Alter Our Understanding of Religion. Edited by Patrick McNamera. Westport: Praeger Publishers, pp. 91-117.

Mannheimer, Andrew H., and Terrence D. Hill. 2015. Deviating from religious norms and the mental health of conservative Protestants. Journal of Religion and Health 54: 1826-38. [CrossRef] [PubMed]

McConnell, Kelly M., Kenneth I. Pargament, Christopher G. Ellison, and Kevin J. Flannelly. 2006. Examining the links between spiritual struggles and symptoms of psychopathology in a national sample. Journal of Clinical Psychology 62: 1469-84. [CrossRef] [PubMed]

Miller, Byron, Sunshine M. Rote, and Verna M. Keith. 2013. Coping with racial discrimination: Assessing the vulnerability of African Americans and the mediated moderation of psychosocial resources. Society and Mental Health 3: 133-50. [CrossRef] [PubMed]

Moradi, Bonnie, and Nadia Talal Hasan. 2004. Arab American persons' reported experiences of discrimination and mental health: The mediating role of personal control. Journal of Counseling Psychology 51: 418-28. [CrossRef]

Mossakowski, Krysia N. 2003. Coping with perceived discrimination: Does ethnic identity protect mental health? Journal of Health and Social Behavior 44: 318-31. [CrossRef] [PubMed]

Nie, Fanhao, and Daniel V. A. Olson. 2016. Demonic influence: The negative mental health effects of belief in demons. Journal for the Scientific Study of Religion 55: 498-515. [CrossRef]

Noh, Samuel, and Violet Kaspar. 2003. Perceived discrimination and depression: Moderating effects of coping, acculturation, and ethnic support. American Journal of Public Health 93: 232-38. [CrossRef] [PubMed]

Paradies, Yin, Jehonathan Ben, Nida Denson, Amanuel Elias, Naomi Priest, Alex Pieterse, Arpana Gupta, Margaret Kelaher, and Gilbert Gee. 2015. Racism as a determinant of health: A systematic review and meta-analysis. PLoS ONE 10: e0138511. [CrossRef] [PubMed]

Pargament, Kenneth I., Bruce W. Smith, Harold G. Koenig, and Lisa Perez. 1998. Patterns of positive and negative religious coping with major life stressors. Journal for the Scientific Study of Religion 37: 710-24. [CrossRef]

Pargament, Kenneth I., Harold G. Koenig, Nalini Tarakeshwar, and June Hahn. 2004. Religious coping methods as predictors of psychological, physical and spiritual outcomes among medically ill elderly patients: A two-year longitudinal study. Journal of Health Psychology 9: 713-30. [CrossRef] [PubMed]

Pargament, Kenneth I., Nichole A. Murray-Swank, Gina M. Magyar, and Gene G. Ano. 2005. Spiritual struggle: A phenomenon of interest to psychology and religion. In Judeo-Christian Perspectives on Psychology: Human Nature, Motivation, and Change. Edited by William R. Miller and Harold D. Delaney. Washington: American Psychological Association, pp. 245-68.

Park, Crystal. 2005. Religion and meaning. In Handbook of the Psychology of Religion and Spirituality. Edited by R. F. Paloutzian and C. L. Park. New York: Guilford Press, pp. 295-314.

Pascoe, Elizabeth A., and Laura Smart Richman. 2009. Perceived discrimination and health: a meta-analytic review. Psychological Bulletin 135: 531-54. [CrossRef] [PubMed]

Pascoe, Anita E., Terrence D. Hill, Krysia N. Mossakowski, and Robert J. Johnson. 2016. Religious involvement and perceptions of control: Evidence from the Miami-Dade Health Survey. Journal of Religion and Health 55: 862-73. [CrossRef] [PubMed]

Schulz, Amy J., Clarence C. Gravlee, David R. Williams, Barbara A. Israel, Graciela Mentz, and Zachary Rowe. 2006. Discrimination, symptoms of depression, and self-rated health among African American women in Detroit: Results from a longitudinal analysis. American Journal of Public Health 96: 1265-70. [CrossRef] [PubMed]

Smith, Timothy B., Michael E. McCullough, and Justin Poll. 2003. Religiousness and depression: Evidence for a main effect and the moderating influence of stressful life events. Psychological Bulletin 129: 614-36. [CrossRef] [PubMed]

Stauner, Nick, Julie J. Exline, Joshua B. Grubbs, Kenneth I. Pargament, David F. Bradley, and Alex Uzdavines. 2016. Bifactor models of religious and spiritual struggles: Distinct from religiousness and distress. Religions 7: article 68. [CrossRef]

Steffen, Patrick R., and Matthew Bowden. 2006. Sleep disturbance mediates the relationship between perceived racism and depressive symptoms. Ethnicity $\mathcal{E}$ Disease 5: 16-21.

Sternthal, Michelle J., David R. Williams, Marc A. Musick, and Anna C. Buck. 2010. Depression, Anxiety, and Religious Life A Search for Mediators. Journal of Health and Social Behavior 51: 343-59. [CrossRef] [PubMed] 
Taylor, John, and R. Jay Turner. 2002. Perceived discrimination, social stress, and depression in the transition to adulthood: Racial contrasts. Social Psychology Quarterly 65: 213-25. [CrossRef]

Trenholm, Penelope. 1998. Negative religious conflict as a predictor of panic disorder. Journal of Clinical Psychology 54: 59-65. [CrossRef]

Uecker, Jeremy E., Christopher G. Ellison, Kevin J. Flannelly, and Amy M. Burdette. 2016. Belief in Human Sinfulness, Belief in Experiencing Divine Forgiveness, and Psychiatric Symptoms. Review of Religious Research 58: 1-26. [CrossRef]

Vaghela, Preeti, and Angelina R. Sutin. 2016. Discrimination and sleep quality among older US adults: The mediating role of psychological distress. Sleep Health 2: 100-8. [CrossRef]

Versey, H. Shellae, and Nicola Curtin. 2016. The differential impact of discrimination on health among Black and White women. Social Science Research 57: 99-115. [CrossRef] [PubMed]

White, Ian R., Patrick Royston, and Angela M. Wood. 2011. Multiple imputation using chained equations: Issues and guidance for practice. Statistics in Medicine 30: 377-99. [CrossRef] [PubMed]

Williams, David R., Yan Yu, James S. Jackson, and Norman B. Anderson. 1997. Racial differences in physical and mental health: Socio-economic status, stress and discrimination. Journal of Health Psychology 2: 335-51. [CrossRef] [PubMed]

Williams, David R., Harold W. Neighbors, and James S. Jackson. 2003. Racial/ethnic discrimination and health: Findings from community studies. American Journal of Public Health 93: 200-8. [CrossRef] [PubMed]

Wilt, Joshua A., Julie J. Exline, Joshua B. Grubbs, Crystal L. Park, and Kenneth I. Pargament. 2016a. God's role in suffering: Theodicies, divine struggle, and mental health. Psychology of Religion and Spirituality 8: 352-62. [CrossRef]

Wilt, Joshua A., Joshua B. Grubbs, Julie J. Exline, and Kenneth I. Pargament. 2016b. Personality, religious and spiritual struggles, and well-being. Psychology of Religion and Spirituality 8: 341-51. [CrossRef]

Wilt, Joshua A., Joshua B. Grubbs, Kenneth I. Pargament, and Julie J. Exline. 2017. Religious and spiritual struggles, past and present: Relations to the big five and well-being. The International Journal for the Psychology of Religion 27: 51-64. [CrossRef]

Wortmann, Jennifer H., Crystal L. Park, and Donald Edmondson. 2011. Trauma and PTSD symptoms: Does spiritual struggle mediate the link? Psychological Trauma: Theory, Research, Practice, and Policy 3: 442-52. [CrossRef] [PubMed]

Yang, Tse-Chuan, and Kiwoong Park. 2015. To what extent do sleep quality and duration mediate the effect of perceived discrimination on health? Evidence from Philadelphia. Journal of Urban Health 92: 1024-37. [CrossRef] [PubMed]

(C) 2017 by the authors. Licensee MDPI, Basel, Switzerland. This article is an open access article distributed under the terms and conditions of the Creative Commons Attribution (CC BY) license (http:/ / creativecommons.org/licenses/by/4.0/). 